\title{
The Adaptation of Inpatient Dignity Scale Into Turkish: A Validity and Reliability Study
}

\author{
Yatan Hasta Haysiyeti Ölçeginin Türkçe ye Uyarlanması: Geçerlilik ve Güvenilirlik Çalışması
}

Kursat Yurdakos

Sivas Cumhuriyet University, Cumhuriyet Social Sciences Vocational School, Department of Health Tourism

Administration, Sivas, Turkey

Correspondence:

Kursat YURDAKOS

Sivas Cumhuriyet University,

Cumhuriyet Social Sciences

Vocational School, Department of

Health Tourism Administration,

Sivas, Turkey

e-mail: yurdakoskursat@gmail.com

\section{Abstract}

In this study, it is aimed to analyze whether the Turkish form of "Inpatient Dignity Scale" is a valid and reliable tool to measure the expectations and satisfaction of the patients related to dignity in their daily care. This is a methodological study. The population of the study includes 2.646 patients receiving inpatient treatment between the dates of January-February 2021.26 of the patients were in psychiatry, 1.123in internal medicine and 1.497 in surgical departments. Stratified sampling method was used to determine how many patients would be included from the clinics, and random sampling method was used in the selection of the patients. The construct validity of the scale was measured by confirmatory factor analysis, internal consistency by Cronbach alpha coefficient and test-retest reliability by Intraclass Correlation Coefficient. DFA regression coefficients and corrected item-total correlation values were as follows respectively: $0.79-0.93$ and $0.66-0.88$ for expectation, and between $0.57-0.89,0.57-0.77$ for satisfaction. Cronbach alpha index was 0.97 for expectation and 0.94 for satisfaction. The test-retest reliability overall ICC value of the scale was 0.99 for expectation and 0.96 for satisfaction. Model fit indices were in the acceptable interval: $\chi 2 / \mathrm{df}=2.88, \mathrm{CFI}=0.96, \mathrm{RMSEA}=0.08$ for expectation and $\chi 2 / \mathrm{df}=2.71, \mathrm{CFI}=0.91, \mathrm{RMSEA}=0.09$ for satisfaction. As a result of the study, it has been revealed that Inpatient Dignity Scale is a valid and reliable assessment tool that can be used in the evaluation of the expectations and satisfaction levels of the patients hospitalized in Turkey regarding dignity in daily care.

Keywords: Inpatient dignity, physician, nurse, scale validity, scale reliability.

\section{Özet}

Bu çalışmada, "Yatan Hasta Haysiyeti Ölçeği” Türkçe formunun hastaların günlük bakımda haysiyet ile ilgili beklentilerini ve memnuniyetlerini ölçmek için geçerli ve güvenilir bir araç olup olmadığının incelenmesi amaçlanmışıtır. Çalış̧ma metodolojik tiptedir. Arastırmanın evrenini Ocak-Subat 2021 tarihlerinde yatarak tedavi gören 2.646 hasta olusturmustur. Hastaların 26’s psikiyatri, 1.123 'ü dahili ve 1.497 'si cerrahi bölümlerin kliniklerindedir. Kliniklerden kaçar hasta alınacağı tabakalı örnekleme; hastaların seçiminde ise basit rasgele örnekleme yöntemi kullanılmıştır. Ölçeğin yapı geçerliliği doğrulayıcı faktör analiziyle, iç tutarlılığı Cronbach alfa katsayısılyla ve test-tekrar test güvenilirliği Intraclass Correlation Coefficient ile ölçülmüștür. DFA standardize regresyon katsayıları ile düzeltilmiş madde- toplam korelasyonu değerleri sırasıyla; beklenti için 0.79-0.93, 0.66-0.88; memnuniyet için 0.57-0.89, 0.57-0.77 arasındadır. Cronbach alfa indeksi beklenti için 0.97 ve memnuniyet için 0.94 'dür. Ölçeğin test tekrar test güvenilirliği genel ICC değeri beklenti için 0.99 ve memnuniyet için 0.96 dir. Model uyum indeksleri kabul edilebilir aralık içindedir: Beklenti için $\chi 2 / \mathrm{df}=2.88$, CFI=0.96, RMSEA $=0.08$; memnuniyet için, $\chi 2 / \mathrm{df}=2.71, \mathrm{CFI}=0.91$, RMSEA=0.09. Araștırmada, Yatan Hasta Haysiyeti Ölceğínin Türkiye’deki hastanelerde yatan hastaların günlük bakımda haysiyetle ilgili beklenti ve memnuniyet düzeylerinin değerlendirilmesinde kullanılabilecek geçerli ve güvenilir bir ölçme aracı olduğu ortaya konmuştur.

Anahtar Kelimeler: Yatan hasta haysiyeti, hekim, hemşire, ölçek geçerlilik, ölçek güvenilirlik.

Received 02.11.2021 Accepted 08.12.2021 Online published 10.12.2021 


\section{Introduction}

Due to the importance of patient rights, the concept of patient dignity has come to the fore in health care. Protecting dignity in health care is an ethical principle. Health ethics and human rights recommend protecting and promoting human dignity during the delivery of health care services (1).

Dignity concept analysis in professional practice and its emphasis in health care were first made in the last half of the 1990s and were generally mentioned in qualitative researches (2-4). These studies provide data regarding to experiences related to dignity of patients and relatives in medical treatment and practice (5). It is certain that patients and their relatives expect health care providers to protect their dignity in the medical treatment and practice process. However, the data in the studies on the content of these expectations are limited. According to the results of the studies, "feeling peaceful" and "feeling given importance" are among the main indicators of dignity. Fenton and Mitchell (6) define patient dignity as patients' feeling physical, emotional and mental comfort. Baillie (7) determined in her qualitative study that patients and staff emphasize three factors in their evaluations about patient dignity. These factors are; a) feelings (feeling comfortable, secure and happy), b) physical appearance, self care and conducive environment, c) behavior (being respected). Baillie (7) summarizes the matters in this content as feelings, staff's control on patients, privacy, being valued and others' behaviors.

In hospitals, patients are usually defenseless against the loss of dignity. The dignity of patients is directly related to the appropriateness of the hospital environment and the behavior of its staff (7). Turnock and Kelleher (8) reported in their study that intensive care patients have a low sense of maintaining their dignity. Maintaining dignity, which is neglected due to the urgency of intervention in life-threatening patients, is also an important issue (9). Geyman (10) considered dignity as one of the five basic needs in patient care, based on the importance of dignity in the care of terminal patients. In this regard, protecting the dignity of the patients in care and treatment process completely depends on the behaviors of health care professionals (11-13). In many cases, the transfer of control to the staff in the hospital and the violation of privacy for compulsory reasons harm the patients' dignity (14). Therefore, it is a serious necessity to reveal the expectations and satisfaction perceptions of patients and their relatives about dignity, which will guide health professionals in the health care process.

The Picker Institute Europe for Help the Aged has evaluated the positive and negative aspects of the dignity perception in the services providing in hospitals and residential facilities by analyzing different studies. According to the analysis, protecting respect, privacy, autonomy, equality and dignity should be primary principles (15). Anderberg et. al (16) deal with the aspects of dignity related to socio-cultural events and internal and external aspects varying from person to person, and emphasize the characteristics (individualized care, control restored, respect, advocacy and sensitive listening), premises (professional knowledge, responsibility, reflection and non-hierarchical organization) and results (strengthening life spirit, an inner sense of freedom, self-respect and successful coping) of protecting dignity in health care. However, slow progresses have been made in developing tools to measure the expectations and satisfactions of patients regarding dignity. Jacelon et. al (17) determine the subscales of the "attributed dignity scale," which they derived from qualitative data with an overall approach, as "Self-Value", "Behavioral Respect-Self" and "Behavioral Respect- Others." Chochinov et. al (18) have developed "The Patient Dignity Inventory" in patients receiving palliative care. They have dealt with eclectic issues such as physical, psychosocial, spiritual and existential under the title of dignity related distress. This tool helps health care professionals to be able to determine the problems that will cause distress for the patients on the verge of death.

The tools obtained as a result of these researches comprise the words of ego, 
esteem and dignity in the cultural content in detail. However, none of these tools has been designed or validated to measure the degree of expectation and satisfaction with respect to dignity based on the observations and experiences of the patients receiving inpatient treatment. In Turkey, no standardized scale has been found to determine the expectation and satisfaction perceptions of the patients receiving inpatient treatment in daily care regarding dignity.

First, Ota et. al (19) in Japan have conducted a study on "the first step towards developing an international patient dignity scale." In 2019, they developed a tool to measure the expectations and satisfactions of hospitalized patients regarding dignity (20). This tool, titled "Inpatient Dignity Scale (IDS)," was developed as a tool that could be applied in intercultural context through the studies in Japan, Singapore and the United Kingdom.

In this study, it is aimed to analyze whether the Turkish form of IDS, developed by Ota et. al (20), is a valid and reliable tool to measure the expectation and satisfaction of the patients in daily care regarding dignity.

\section{Material and Methods}

\section{Study design}

This methodological study was conducted in Sivas Cumhuriyet University, Healthcare Services Application and Research Hospital in January and February 2021.

\section{Ethics}

The permission necessary for the right of use of the IDS was obtained from Katsumata Ota via e-mail in $27 / 11 / 220$. The study was approved by the Ethical Committee of Sivas Cumhuriyet University Noninvasive Clinical Researches (16/12/2020 dated and 22 numbered), and afterwards, institutional permission was received from the Hospital Chief Physician.

Even if the questionnaires were planned to be applied by face to face interview technique, they were applied on the phone because of covid-19 pandemic in January and February and the visitor constraint in hospitals. The consents of the patients were obtained in the beginning of the interviews. The patients were reminded that they can stop the interview whenever they demand, and the participants answering all the questions were included in the evaluation.

\section{Study population}

The population of the study included 2.646 patients receiving inpatient treatment in January and February 2021. 26 of the participants stayed in psychiatric clinic, 1.123 in the internal diseases clinic and 1.497 in the surgical clinic. In scale development and adaptation studies, participant number should be 5-10 times the number of items $(21,22)$. Therefore, 210 patients were determined as the sample by considering 10 times of the 21 items in the original scale. Stratified sampling method was used to determine how many patients would be included from which clinics. 26, 79 and 105 patients were included in the sample from the clinics of psychiatric, internal and surgical departments respectively by this method. Simple random sampling method, which is among random sampling methods was used to determine which patients would be included in the designated sample units.

\section{Data collection tools}

\section{Two forms were used to collect the data}

Introductory information form: It included 9 questions evaluating the sociodemographic characteristics of the patients such as age, gender, marital status, family status and profession.

Inpatient Dignity Scale: The scale, which is the result of the study conducted by Ota et. al (20) in Japan, Singapore and England, was developed to evaluate the expectation and satisfaction of inpatients regarding dignity in daily care. It is a five-point Likert scale including 21 items and four subscales. The 10th, 15th, 16th, 17th and 18th items are excluded in evaluating dignity expectation and 7 th, 13th and 20th items in evaluating dignity satisfaction. The score interval to be obtained from the scale is $16-80$ for dignity expectation and 18-90 for dignity satisfaction. The scale does not have a cutoff 
point, and a high score shows positive dignity expectation and satisfaction. Cronbach's alpha coefficient of the original scale was found as 0.85 , Kaiser-Meyer-Olkin (KMO) sampling adequacy criteria were found as .88 and 93 for expectation and satisfaction respectively (20). It was determined that the factor load of each item in dignity expectation and satisfaction was higher than 0.50 (23) and all factors had a significant relation with the whole scale (20).

\section{Content validity}

In order to translate the IDS from its English version into Turkish, a forward and backward procedure was used. The scale was translated into Turkish by two instructors speaking English very well. In the next step, the other two instructors, who did not see the original English scale and had a good level of English, translated the Turkish version back into English, and the linguistic consistency between the two forms was examined. The quality and number of experts (between the range of 5 and 40) are of great importance in obtaining objective results in the calculations to be made to determine the content validity (24-26). Within this framework, the commission including 10 specialists compared the original scale with the draft scale that was translated from Turkish into English, and they evaluated it by Content Validity Ratio (CVR) and Content Validity Index (CVI) in terms of appropriateness and clarity. The specialists reported their opinions as "appropriate," "appropriate but should be rearranged" or "should be omitted" for each item according to the technique developed by Lawshe (24). In order to determine the content validity of the items to be included in the scale, the qualitative data obtained in accordance with the expert opinions were transformed to quantitative data by calculating CVR and CVI. The calculations were made by Microsoft Excel 2016 software.

CVR values were obtained in line with the opinions stated by the 10 experts regarding items, and the 13th item stating that "Nurse of my gender give me care" had the CVR of a negative value was directly excluded from the scale. Then, the statistical significance of the CVR values of the items having the values higher than zero, hence whether they would be included in the scale was determined by considering Content Validity Criterion (CVC). According to the 10 specialists participating in the study, CVC value was 0.474. After one item (13th item) was removed, it was seen that CVR values of the rest 20 items were higher than $\mathrm{CVC}$ value $(=0.474)$. Therefore, these 20 items having values above this critical value stayed in the scale that was being adapted.

When CVI value is higher than CVC value, the content validity of the items in a scale is accepted statistically significant (24). CVI value of the study was calculated after one item removed from the scale, and it was found as 0.792 . CVI value obtained was higher than the CVC value (CVI $>\mathrm{CVC})$, and the content validity of the items staying in the scale was determined statistically significant $(p<0.05)$. After the content validity analyzes of the scale, the ones among the remaining 20 items with the opinion of "must be corrected by at least one expert" were reviewed and corrected in line with expert opinions, and finally a scale with content validity was obtained. This version was tested on 30 subjects including inpatients by the first author. Problems such as perception and obscurity that patients stated for each item and their opinions regarding the scale were noted. After a minor revision, the final version of the scale was accepted.

\section{Construct validity}

Confirmatory factor analysis (CFA) method was used to compare the construct validity of the scale having four factors as in the original culture. Before the factor analysis, the adequacy of the sample and whether the distribution of the data was normal was evaluated by "tests for normality and outliers." $\chi 2 / \mathrm{df}$ value was calculated for an acceptable fitness in CFA ( $<5$ acceptable, $<2$ perfect) (27). Model fitness was analyzed by using goodness of fit index (GFI), root mean square error of approximation (RMSEA), confirmatory fit index (CFI), normed fit index (NFI) and Tucker-Lewis index (TLI). In a good model, GFI and CFI should be $>0,90$, NFI and TLI $>0,95$ and RMSEA $<0,08$ (28). 


\section{Reliability}

The reliability features of the scale were analyzed by internal consistency method. Cronbach alpha coefficient was used to evaluate the internal consistency of the questionnaire. In order to evaluate the stability of the scale, test-retest reliability was analyzed by using Intraclass Correlation Coefficient (ICC), and the values of $<0,5$ (poor), $0,5-0,9$ (good) and $>0,9$ (perfect) were accepted as boundary values (29). 40 inpatients were invited to fill in the questionnaires at a twoweek interval in order to determine the scale reliability by test-retest.

All analyses were performed by using IBM Statistical Package for the Social Sciences Statistics (SPSS) 22 and IBM Analysis of Moment Structures (AMOS) 22.

\section{Constraints of the research}

The research is a monocentral study and was conducted in a hospital delivering tertiary health care services. Participants were included from almost all clinics except for the pediatric clinic. Those above the age of 18 were included in the study.

\section{Results}

$50.5 \%$ of the patients included in the study were female, $37.1 \%$ were in the age group of $40-59$ and $49 \%$ were graduates of elementary school. It was determined that $58.6 \%$ of the patients did not work, $71.4 \%$ of them married and $99 \%$ were living with family members. It was found that $58.1 \%$ of the patients had been hospitalized at least three times up to that time, $59 \%$ of them stayed in the hospital less than six days in the period the study was being conducted and 50\% hospitalized in surgical clinics (Table 1).

Table 1. Socio-demographic characteristics of the patients $(n=210)$

\begin{tabular}{|c|c|c|}
\hline Characteristics & Number & $\%$ \\
\hline \multicolumn{3}{|l|}{ Gender } \\
\hline Female & 106 & $\mathbf{5 0 . 5}$ \\
\hline Male & 104 & 49.5 \\
\hline \multicolumn{3}{|c|}{ Age $(M \pm S D(50.5 \pm 17.3))$} \\
\hline 20-39 & 61 & 29.0 \\
\hline $40-59$ & 78 & 37.1 \\
\hline 60 and above & 71 & 33.8 \\
\hline \multicolumn{3}{|l|}{ Marital status } \\
\hline Single & 60 & 28.6 \\
\hline Married & 150 & 71.4 \\
\hline \multicolumn{3}{|l|}{ Educational status } \\
\hline Elementary & 103 & 49.0 \\
\hline High school & 52 & 24.8 \\
\hline University & 55 & 26.2 \\
\hline \multicolumn{3}{|l|}{ Family situation } \\
\hline Living alone & 2 & 1.0 \\
\hline Living with family & & \\
\hline members & 208 & 99.0 \\
\hline \multicolumn{3}{|l|}{ Occupation } \\
\hline Not working & 123 & 58.6 \\
\hline Working & 87 & 41.4 \\
\hline \multicolumn{3}{|c|}{ Number of hospitalization } \\
\hline Once & 34 & 16.2 \\
\hline Twice & 54 & 25.7 \\
\hline 3 times and above & 122 & 58.1 \\
\hline \multicolumn{3}{|c|}{$\begin{array}{l}\text { Number of hospitalization } \\
\text { day at the moment }\end{array}$} \\
\hline$<6$ & 124 & 59.0 \\
\hline $6-10$ & 40 & 19.0 \\
\hline $11 \geq$ and $\uparrow$ & 46 & 22.0 \\
\hline
\end{tabular}




\begin{tabular}{lcc}
\hline Hospitalization clinic & & \\
$\quad$ Psychiatric department & 26 & $\mathbf{1 2 . 4}$ \\
$\quad$ Internal diseases & 79 & $\mathbf{3 7 . 6}$ \\
departments & & \\
$\quad$ Surgical departments & 105 & $\mathbf{5 0 . 0}$ \\
\hline Discharge & & \\
$\quad$ No & $\mathbf{1 5 4}$ & $\mathbf{7 3 . 3}$ \\
$\quad$ Yes & $\mathbf{5 6}$ & $\mathbf{2 6 . 7}$ \\
\hline Mean $S D=$ Standard Deviation. & &
\end{tabular}

Descriptive statistics for the dignity expectation and satisfaction of the patients were presented in Table 2. A significant relation was determined between expectation and satisfaction $(\mathrm{r}=.16-49)$. The satisfaction average scores of the items were found statistically significant when compared to the expectations $(\mathrm{p}<.05)$.

Table 2. Patient Expectations and Satisfaction in Phase 2.

\begin{tabular}{|c|c|c|c|c|c|c|c|c|}
\hline \multirow[t]{2}{*}{ Items } & \multirow[b]{3}{*}{$\begin{array}{l}(\mathrm{P} / \mathrm{N}) \text { treat and care for me as a living human } \\
\text { being rather than an object. }\end{array}$} & \multicolumn{2}{|c|}{$\begin{array}{l}\text { Expectations } \\
\text { Correlatio }\end{array}$} & \multicolumn{2}{|c|}{ Satisfaction } & \multirow[t]{2}{*}{$p$} & \multirow{2}{*}{\multicolumn{2}{|c|}{$\mathbf{n}$}} \\
\hline & & $\mathrm{n}$ & $\mathrm{M} \pm \mathrm{SD}$ & $\mathrm{n}$ & $\mathrm{M} \pm \mathrm{SD}$ & & & \\
\hline Exp-1/Sat-1 & & 210 & $4.37 \pm 0.72$ & 210 & $4.52 \pm 0.55$ & .005 & .25 & $<.001$ \\
\hline Exp-2/Sat-2 & $\begin{array}{l}(\mathrm{P} / \mathrm{N}) \text { maintain eye contact with me while } \\
\text { talking. }\end{array}$ & 210 & $4.32 \pm 0.70$ & 210 & $4.45 \pm 0.54$ & .024 & .16 & $<.05$ \\
\hline Exp-3/Sat-3 & $(\mathrm{P} / \mathrm{N})$ respect me as a human being. & 210 & $4.38 \pm 0.72$ & 210 & $4.42 \pm 0.54$ & .021 & .19 & $<.05$ \\
\hline Exp-4/Sat-4 & $(\mathrm{P} / \mathrm{N})$ listen to me attentively. & 210 & $4.35 \pm 0.71$ & 210 & $4.47 \pm 0.55$ & .030 & .17 & $<.05$ \\
\hline Exp-5/Sat-5 & $(\mathrm{P} / \mathrm{N})$ always use polite language. & 210 & $4.33 \pm 0.71$ & 210 & $4.44 \pm 0.54$ & .041 & .33 & $<.001$ \\
\hline Exp-6/Sat-6 & $\begin{array}{l}(\mathrm{P} / \mathrm{N}) \text { are polite to my family as well as to } \\
\text { me. }\end{array}$ & 210 & $4.34 \pm 0.71$ & 210 & $4.45 \pm 0.55$ & .031 & .28 & $<.001$ \\
\hline Exp-7 & $\begin{array}{l}(\mathrm{P} / \mathrm{N}) \text { talk to me at my eye level by sitting on } \\
\text { a chair or bending. }\end{array}$ & 210 & $4.28 \pm 0.71$ & & & & & \\
\hline Exp-8/Sat-8 & $\begin{array}{l}(\mathrm{P} / \mathrm{N}) \text { give my needs or expectations priority } \\
\text { in their everyday practice. }\end{array}$ & 210 & $4.27 \pm 0.70$ & 210 & $4.48 \pm 0.55$ & .000 & .38 & $<.001$ \\
\hline Exp-9/Sat-9 & $\begin{array}{l}(\mathrm{P} / \mathrm{N}) \text { greet me first when they see me in the } \\
\text { hospital. }\end{array}$ & 210 & $4.33 \pm 0.71$ & 210 & $4.45 \pm 0.54$ & .023 & .37 & $<.001$ \\
\hline Sat-10 & $(\mathrm{P} / \mathrm{N})$ treat my pain promptly. & & & 210 & $4.46 \pm 0.55$ & & & \\
\hline Exp-11/Sat-11 & $\begin{array}{l}(\mathrm{P} / \mathrm{N}) \text { let me participate in the decision- } \\
\text { making processes regarding my own } \\
\text { treatment choices. }\end{array}$ & 210 & $4.30 \pm 0.70$ & 210 & $4.43 \pm 0.54$ & .010 & .30 & $<.001$ \\
\hline Exp-12/Sat-12 & $\begin{array}{l}(\mathrm{P} / \mathrm{N}) \text { offer different choices so I can decide } \\
\text { on my treatment. }\end{array}$ & 210 & $4.31 \pm 0.70$ & 210 & $4.42 \pm 0.54$ & .043 & .23 & $<.001$ \\
\hline Exp-13/Sat-13 & $\begin{array}{l}(\mathrm{P} / \mathrm{N}) \text { understand my pain and approach my } \\
\text { situation positively. }\end{array}$ & 210 & $4.29 \pm 0.69$ & 210 & $4.39 \pm 0.53$ & .040 & .30 & $<.001$ \\
\hline Sat-14 & $(\mathrm{P} / \mathrm{N})$ are always smiling for me. & & & 210 & $4.40 \pm 0.54$ & & & \\
\hline Sat-15 & $\begin{array}{l}(\mathrm{P} / \mathrm{N}) \text { talk to me privately about my issues } \\
\text { without allowing others to hear. }\end{array}$ & & & 210 & $4.44 \pm 0.55$ & & & \\
\hline Sat-16 & $\begin{array}{l}(\mathrm{P} / \mathrm{N}) \text { keep me protected with covering or } \\
\text { clothing while providing medical treatment } \\
\text { or nursing care. }\end{array}$ & & & 210 & $4.37 \pm 0.53$ & & & \\
\hline Sat-17 & $\begin{array}{l}(\mathrm{P} / \mathrm{N}) \text { draw the bedside curtain or shut the } \\
\text { door to maintain privacy during medical } \\
\text { treatment or nursing care. }\end{array}$ & & & 210 & $4.48 \pm 0.55$ & & & \\
\hline Exp-18/Sat-18 & $\begin{array}{l}(\mathrm{P} / \mathrm{N}) \text { share the necessary information for my } \\
\text { medical treatment with other members of the } \\
\text { healthcare team. }\end{array}$ & 210 & $4.34 \pm 0.70$ & 210 & $4.49 \pm 0.55$ & .006 & .24 & $<.001$ \\
\hline Exp-19 & $\begin{array}{l}(\mathrm{P} / \mathrm{N}) \text { do not disclose my sensitive } \\
\text { information, such as family issues, to } \\
\text { healthcare workers other than my own } \\
\text { physicians and nurses. }\end{array}$ & 210 & $4.35 \pm 0.71$ & & & & & \\
\hline Exp-20/Sat-20 & $\begin{array}{l}(\mathrm{P} / \mathrm{N}) \text { do not collect information that is } \\
\text { unnecessary for my medical treatment or } \\
\text { nursing care. }\end{array}$ & 210 & $4.36 \pm 0.71$ & 210 & $4.50 \pm 0.55$ & .002 & .49 & $<.001$ \\
\hline
\end{tabular}


CFA standardized regression coefficients, namely factor loads, and corrected itemtotal correlation values for expectation were between the range of 0.79 and 0.93 and between 0.66 and 0.88 respectively, they were in the range of 0.57 and 0.89 and between 0.57 and 0.77 for satisfaction. The overall Cronbach alpha index of the internalreliability of the scale was 0.97 ($0.79-0.94$ in subscales) for expectation and $0.94(-0.77-0.88)$ for satisfaction. The overall ICC value of the test-retest reliability of the scale was $0.99(95 \% \mathrm{CI}-$ $0.86,0.97)$ for expectation and $0.96(95 \%$ CI $-0.76,0.93$ ) for satisfaction (Table 3 ).

Table 3. CFA factor loading, corrected item-total correlation, Cronbach $\alpha$ and Intraclass Correlation Coefficient $(n=210)$ for the patient expectation and satisfaction

\begin{tabular}{|c|c|c|c|c|}
\hline \multicolumn{5}{|l|}{ Expectations } \\
\hline & $\begin{array}{c}\text { CFA } \\
\text { factor } \\
\text { loading }\end{array}$ & $\begin{array}{c}\text { Corrected } \\
\text { Item-Total } \\
\text { Correlation }\end{array}$ & $\begin{array}{c}\text { Cronbach } \\
\alpha\end{array}$ & $\mathrm{ICC}$ \\
\hline F1: Respect as a human being & & & .94 & .97 \\
\hline $1 \quad(\mathrm{P} / \mathrm{N})$ treat and care for me as a living human being rather than an object. & .83 & .80 & & \\
\hline $2 \quad(\mathrm{P} / \mathrm{N})$ maintain eye contact with me while talking. & .86 & .85 & & \\
\hline$(\mathrm{P} / \mathrm{N})$ respect me as a human being. & .87 & .84 & & \\
\hline$(\mathrm{P} / \mathrm{N})$ listen to me attentively. & .84 & .80 & & \\
\hline$(\mathrm{P} / \mathrm{N})$ always use polite language. & .87 & .85 & & \\
\hline$(\mathrm{P} / \mathrm{N})$ are polite to my family as well as to me. & .85 & .81 & & \\
\hline F2: Respect for personal feeling and time & & & .91 & .95 \\
\hline $7 \quad(\mathrm{P} / \mathrm{N})$ talk to me at my eye level by sitting on a chair or bending. & .85 & .83 & & \\
\hline$(\mathrm{P} / \mathrm{N})$ give my needs or expectations priority in their everyday practice. & .86 & .85 & & \\
\hline$(\mathrm{P} / \mathrm{N})$ greet me first when they see me in the hospital. & .88 & .79 & & \\
\hline $13 \quad(\mathrm{P} / \mathrm{N})$ understand my pain and approach my situation positively. & .82 & .73 & & \\
\hline F3: Respect for privacy & & & .92 & .97 \\
\hline $\begin{array}{l}18(\mathrm{P} / \mathrm{N}) \text { share the necessary information for my medical treatment with other } \\
\text { members of the healthcare team. }\end{array}$ & .90 & .85 & & \\
\hline $\begin{array}{l}19(\mathrm{P} / \mathrm{N}) \text { do not disclose my sensitive information, such as family issues, to } \\
\text { healthcare workers other than my own physicians and nurses. }\end{array}$ & .86 & .81 & & \\
\hline $\begin{array}{l}20(\mathrm{P} / \mathrm{N}) \text { do not collect information that is unnecessary for my medical treatment or } \\
\text { nursing care. }\end{array}$ & .93 & .88 & & \\
\hline F4: Respect for autonomy & & & .79 & .86 \\
\hline $\begin{array}{l}11(\mathrm{P} / \mathrm{N}) \text { let me participate in the decision-making processes regarding my own } \\
\text { treatment choices. }\end{array}$ & .83 & .66 & & \\
\hline $12 \quad(\mathrm{P} / \mathrm{N})$ offer different choices so I can decide on my treatment. & .79 & .66 & & \\
\hline \multicolumn{5}{|l|}{ Satisfaction } \\
\hline & $\begin{array}{l}\text { DFA } \\
\text { factor } \\
\text { loading }\end{array}$ & $\begin{array}{c}\text { Corrected } \\
\text { Item-Total } \\
\text { Correlation }\end{array}$ & $\begin{array}{c}\text { Cronbach } \\
\alpha\end{array}$ & ICC \\
\hline F1: Respect for personal feeling and time & & & .88 & .91 \\
\hline $8 \quad(\mathrm{P} / \mathrm{N})$ give my needs or expectations priority in their everyday practice. & .68 & .57 & & \\
\hline$(\mathrm{P} / \mathrm{N})$ greet me first when they see me in the hospital. & .70 & .63 & & \\
\hline $10 \quad(\mathrm{P} / \mathrm{N})$ treat my pain promptly. & .72 & .66 & & \\
\hline $13 \quad(\mathrm{P} / \mathrm{N})$ understand my pain and approach my situation positively. & .76 & .73 & & \\
\hline $14 \quad(\mathrm{P} / \mathrm{N})$ are always smiling for me. & .74 & .69 & & \\
\hline $15(\mathrm{P} / \mathrm{N})$ talk to me privately about my issues without allowing others to hear. & .57 & .57 & & \\
\hline $\begin{array}{l}16(\mathrm{P} / \mathrm{N}) \text { keep me protected with covering or clothing while providing medical } \\
\text { treatment or nursing care. }\end{array}$ & .64 & .62 & & \\
\hline $\begin{array}{l}17(\mathrm{P} / \mathrm{N}) \text { draw the bedside curtain or shut the door to maintain privacy during medical } \\
\text { treatment or nursing care. }\end{array}$ & .66 & .60 & & \\
\hline F2: Respect as a human being & & & .87 & .93 \\
\hline $1 \quad(\mathrm{P} / \mathrm{N})$ treat and care for me as a living human being rather than an object. & .79 & .74 & & \\
\hline$(\mathrm{P} / \mathrm{N})$ maintain eye contact with me while talking. & .72 & .66 & & \\
\hline$(\mathrm{P} / \mathrm{N})$ respect me as a human being. & .67 & .61 & & \\
\hline$(\mathrm{P} / \mathrm{N})$ listen to me attentively. & .68 & .64 & & \\
\hline$(\mathrm{P} / \mathrm{N})$ always use polite language. & .71 & .65 & & \\
\hline$(\mathrm{P} / \mathrm{N})$ are polite to my family as well as to me. & .74 & .66 & & \\
\hline F3: Respect for autonomy & & & .87 & .88 \\
\hline $\begin{array}{l}11(\mathrm{P} / \mathrm{N}) \text { let me participate in the decision-making processes regarding my own } \\
\text { treatment choices. }\end{array}$ & .89 & .77 & & \\
\hline $12 \quad(\mathrm{P} / \mathrm{N})$ offer different choices so I can decide on my treatment. & .86 & .77 & & \\
\hline F4: Respect for privacy & & & .77 & .76 \\
\hline $18(\mathrm{P} / \mathrm{N})$ share the necessary information for my medical treatment with other & .78 & .62 & & \\
\hline
\end{tabular}




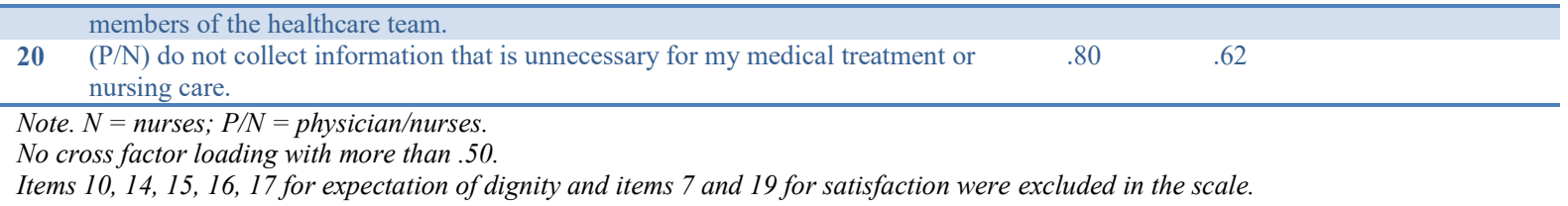

CFA fit indices are within the acceptable range for patient dignity expectation and satisfaction (Table 4).

Table 4. CFA Model Fit Indices

\begin{tabular}{lcc}
\hline Indices & Expectation & Satisfaction \\
\hline$\chi^{2} / \mathbf{d f}$ & 2.88 & 2.71 \\
$\boldsymbol{\gamma}^{2}$ & 230.79 & 332.73 \\
df & 80 & 123 \\
GFI & .87 & .90 \\
RMSEA & .08 & .09 \\
CFI & .96 & .91 \\
NFI & .95 & .94 \\
TLI & .97 & .96 \\
\hline
\end{tabular}

\section{Discussion}

In the study, when the original version, meanly expectations (F1: Respect as a human being; F2: Respect for personal feeling and time; F3: Respect for privacy; F4: Respect for autonomy) and satisfactions (F1: Respect for personal feeling and time; F2: Respect as a human being; F3: Respect for autonomy; F4: Respect for privacy) of the inpatients regarding dignity in daily care, was evaluated it was determined that the four subscales were statistically valid and reliable in Turkish translation.

In the first stage, the linguistic equivalence of the original language of the scale and the Turkish form, which was translated from the original language, was examined. According to the result obtained from the stage performed to determine whether the Turkish and English forms of the IDS are equal in terms of language, the 13th item including the statement "Nurse of my gender give me care", which had a below zero CVR was directly excluded from the scale. After omitting an item, the CVI value was calculated. CVI value obtained was higher than CVC (CVI>CVC), and the content validity of the remaining items in the scale was determined statistically significant. This situation indicates an acceptable content validity according to Lawshe $(20,25)$. The reason of omitting this item from the scale according to the opinions of the specialists can be explained as that nurses working in the hospitals in Turkey are mostly female and the relevant item is not valid for male patients. The fact that the items in two forms were statistically significant after the exclusion of an item revealed that the linguistic equivalence of the original form and the Turkish form was adequate.

CFA method was used to compare a fourfactor construct validity of the scale as in the original culture. According to CFA result, the standardized regression coefficient of the items, meanly factor loads, are above the cutoff point of 0.50 and the fit indices $\left(\chi^{2} / \mathrm{df}\right.$, GFI, RMSEA, CFI, NFI and TLI) are in the acceptable range. The psychometric values of this scale was found above the limit value and as "acceptable." Considering the acceptable fit indices of the IDS for CFA, it can be stated that the four-factor model for the dignity expectations and satisfactions of inpatients in daily care provides good fit and the factor structure of the original scale is in accord with the factor structure of the Turkish form.

In the second stage, the reliability characteristics of the scale was analyzed. In evaluating internal consistency, Cronbach alpha coefficient was used for each factor, and ICC values were used in test-retest reliability. In the study, the Cronbach alpha coefficient of the IDS for the dignity expectations of the 
inpatients in daily care is 0.97 , and it is in the range of 0.79 and 0.94 for the subscales. The Cronbach alpha coefficient is 0.94 for satisfaction, and it is in the range of 0.77 and 0.88 for the subscales. For the test-retest reliability of the scale, expectation ICC value is 0.99 and satisfaction ICC value is 0.96 . These results reveal a high level of reliability. The Cronbach alpha coefficient in the subscales of the original study is in the range of $0.72-0.88$ for the dignity expectations of the patients in daily care, and in the range of $0.72-0.90$ for the satisfactions (20). The fitter the items of a scale are, the higher alpha coefficient is (30). The acceptable value was stated as 0.70 in the internal consistency coefficients' evaluation of the scale (31). Considering this criterion, it is seen that the scale provides the predicted reliability coefficients. In the evaluation of item-total correlation, it is understood that the item-total correlations are adequate, considering that the items with 0.57 and higher pick out (32) the patients well in terms of the criterion to be measured.

As presented in Table 2, according to the ttest result, the average satisfaction scores of the items were found statistically high level of significant when compared to the expectation scores. In addition, average satisfaction scores of the patients had positive, low and significant correlations with expectation scores. Although the average satisfaction scores of each item were determined higher than the expectation scores, we can indicate the items having the highest score averages for the dignity expectations of the inpatients in daily care. In this regard, the 1st, 3rd, 4th and 20 th items became prominent. The 1st, 3rd and 4th items are related to respect for human and the 20th item is related to privacy. The primary task of physicians and nurses is to care and respect human health, life and personality (33). In the study, patients' had high expectations from those providing health

\section{REFERENCES}

1. Jacobson N. Dignity and health: a review. Soc Sci Med 2007;64:292-302.

2. Shotton L, Seedhouse D. Practical dignity in caring. Nurs Ethics 1998;5:246-55.

3. Mains ED. Concept clarification in care services in this respect. Although health care professionals provide health care services with limited number of staff and excess work load, patients expect them to listen to them carefully, respect and consider them as human beings. Patients expect to be respected and treated in accordance with their culture and values during the treatment process. Similar to the original scale, patient expectations about privacy also came to the fore in the study. Privacy is one of the basic concepts of dignity and physicians/nurses must ensure that the physical, mental and social privacy of individuals they serve is protected. They must conduct the medical evaluations related to the health status of patients confidential (34). On the other hand, the 1st and 20th items, which had high scores for expectation, obtained the highest scores also for satisfaction. It was determined in the study that patients' respect and privacy expectations regarding dignity in daily care were very strong, and they were highly satisfied with the physicians and nurses in this respect.

\section{Conclusion}

Consequently, depending on the study findings, it was revealed that IDS was a valid and reliable measurement tool that could be used in the evaluation of dignity expectation and satisfaction levels of patients hospitalized in the hospitals in Turkey in daily care. The scale adapted into Turkish has adequate psychometric features to be used in practice. The findings reveal that IDS can be used in the researches to be conducted in Turkey.

We recommend to apply IDS, which we believe is important to evaluate the expectations and satisfactions of inpatients regarding dignity in daily care, since it involves main fields (e.g.respect and privacy).

professional practice: dignity. $J$ Adv Nurs 1994;19:947-53.

4. Haddock J. Towards further clarification of the concept of 'dignity'. J Adv Nurs 1996;24:924-31. 
5. Transvåg $\mathrm{O}$, Synnes $\mathrm{O}$, McSherry W. Stories of dignity within healthcare: research, narratives and theories. Nurs Stand 2017;31:30.

6. Fenton E, Mitchell T. Growing old with dignity: a concept analysis. Nurs Older People 2002;14:19-21.

7. Baillie L. Patient dignity in an acute hospital setting: A case study. Int J Nurs Stud 2009;46:23-36.

8. Turnock C, Kelleher M. Maintaining patient dignity in intensive care settings. Intensive Crit Care Nurs 2001;17:144-54.

9. Chochinov HM. Dying, dignity, and new horizons in palliative end-of-life care. CA Cancer J Clin 2006;56:84-103.

10. Geyman JP. Dying and death of a family member. J Fam Pract 1983;17:125-34.

11. Rousseau P. Death with dignity: is there such a thing? J Pain Symptom Manage 2017;54:936-37.

12. Danbury CM, Waldmann CS. Ethics and law in the intensive care unit. Best Pract Res Clin Anaesthesiol 2006;20:598-603.

13. Ohlén J. Violation of dignity in care-related situations. Res Theory Nurs Pract 2004;18:371-85.

14. Matiti MR. Patient dignity in nursing: a phenomenological study. Thesis. University of Huddersfield 2002.

15. Magee H, Parsons S, Askham J. Measuring dignity in care for older people: a research report for help the aged. Oxford, UK: Picker Institute; 2008; Date of access 01 June 2021. https://www.communitycare.co.uk/2009/01 /09/research-realities-measuring-dignity-incare- for-older-people

16. Anderberg $\mathrm{P}$, Lepp $\mathrm{M}$, Berglund AL, Segesten K. Preserving dignity in caring for older adults: a concept analysis. $J$ Adv Nurs 2007;59:635-643.

17. Jacelon CS, Dixon J, Knafl KA. Development of the attributed dignity scale. Res Gerontol Nurs 2009;2:202-13.

18. Chochinov HM, Hassard T, McClement S, et al. The Patient Dignity Inventory: a novel way of measuring dignity-related distress in palliative care. J Pain Symptom Manag 2008;36:559-71.

19. Ota K, Yahiro M, Eguchi A, et al. Towards creating an International Patient Dignity Scale: the development of a Japanese version as the first step. In: The 13th International Nursing Ethics Conference; 4th e 6th October; 2012; International Conference of Nursing Ethics, Izmir,Turkey.http://hemarge.org.tr/haber/13 _uluslararasi_he msirelikte_etik_kongresi_$\overline{3} . \mathrm{html}$

20. Ota K, Maeda J, Gallagher A, et al. Development of the Inpatient Dignity Scale Through Studies in Japan, Singapore, and the United Kingdom. Asian Nursing Research 2019;13:76-85.

21. Floyd FJ, Widaman KF. Factor analysis in the development and refinement of clinical assessment instruments. Psychol Assess 1995; 7:286-99.

22. Jöreskog KG, Sörbom D. LISREL-8 user's reference guide. Lincolnwood, IL: Scientific International. 1996

23. Lluch-Canut T, Puig-Llobet M, SánchezOrtega A, Roldán-Merino J, Ferré-Grau C. Assessing posi-tive mental health in people with chronic physical health problems: correlations with socio-demogra-phic variables and physical health status. $B M C$ Public Health 2013;13:928.

24. Lawshe $\mathrm{CH}$. A quantitative approach to content validity. Personnel Psychology 1975;28:563-75.

25. Ayre C, Scally AJ. Critical values for Lawshe's content validity ratio. Revisiting the original methods of calculation. Measurement and Evaluation in Counseling and Development 2014;47:79-86.

26. Veneziano L, Hooper J. A method for quantifying content validity of health-related questionnaires. Am J Health Behav 1997;21:67-70.

27. Kline RB.. Principles and Practice of Structural Equation Modeling. 4th Ed. New York, Londan, The Guilford Press, 2016:188336.

28. Hair Jr JF, Black WC, Babin BJ, Anderson RE. . Multivariate data analysis. 7th ed. Nova Jersey: Pearson Education Limited. 2013

29. Crocker L, Algina J. Introduction to classical and modern test theory. Ohio (ABD): Cengage Learning press, 1986:287-477.

30. Tavakol M, Dennick R. Making sense of cronbach's alpha. Int J Med Educ 2011;2:5355 .

31. Özdamar K. Paket Programlar ile İstatistiksel Veri Analizi I. Eskişehir, Kaan Kitabevi. 1999

32. Büyüköztürk Ș. Sosyal Bilimler İçin Veri Analizi El Kitabı. Sekizinci bask1, Ankara: Pegem Yayıncılık. 2007

33. Er Ü. Sağlık Hukuku. 2. Baskı, Ankara, Savaş Kitabevi. 2019

34. Berna A, Şahinoğlu PS. (). Tibbi Etik: Tanımı, İçeriği, Yöntemi ve Başlıca Konuları. Ankara Tip Mecmuas1, 1995:48:323. 